CONFIDENTIAL INFORMATION

DEADLINE: 31 MAY 2013

\title{
2013-024 YEOMANITE
}

\section{$\mathrm{Pb}_{2} \mathrm{O}(\mathrm{OH}) \mathrm{Cl}$}

Orthorhombic Space group: Pnma

$a=6.585(10) \quad b=3.855(6) \quad c=17.26(1) \AA$

$V=438(1) \AA^{3}$

$Z=4$

R.W. Turner ${ }^{1} *$, O.I. Siidra $^{2}$, M.S. Rumsey ${ }^{3}$, Y.S. Polekhovsky ${ }^{4}$, S.V. Krivovichev ${ }^{2}$, Y.L. Kretser ${ }^{5}$, C.J. Stanley ${ }^{3}$, and J. Spratt ${ }^{3}$

${ }^{1}$ The Drey, Allington Track, Allington, Salisbury SP4 0DD, Wiltshire, UK

${ }^{2}$ Department of Crystallography, Geological Faculty, St Petersburg State University, University Embankment 7/9, St Petersburg 199034, Russia

${ }^{3}$ Department of Earth Sciences, Natural History Museum, Cromwell Road, London SW7 5BD, UK

${ }^{4}$ Department of Mineral Deposits, St Petersburg State University, University Embankment 7/9, 199034 St Petersburg, Russia

${ }^{5}$ V.G. Khlopin Radium Institute, Roentgen Street 1, 197101 St Petersburg, Russia

*E-mail: rturner@imbuia-holdings.com

\section{OCCURRENCE}

UK.

The mineral occurs in the Torr Works (Merehead) Quarry, East Cranmore, Somerset,

Yeomanite is associated with mendipite, as a cavity filling in manganese oxide pods.

Other oxyhalide minerals that are found hosted in mendipite include diaboleite, chloroxiphite and paralaurionite. Secondary $\mathrm{Pb}$ and $\mathrm{Cu}$ minerals, including mimetite, wulfenite, cerussite, hydrocerussite, malachite, and crednerite also occur in the same environment. Gangue minerals associated with mineralised manganese pods include aragonite, calcite and barite. Undifferentiated pod-forming Mn oxides are typically a mixture of manganite and pyrolusite, associated with Fe oxyhydroxides such as goethite (Turner, 2006).

The origin of the manganese oxide pods and the lead oxychloride phases that they enclose has been debated for many years. Turner (2006) suggested that all the lead oxychlorides were formed when galena deposits in Carboniferous limestones were locally exposed to seawater. Surface oxidation of the galena initiated the deposition of manganeserich phases, which adsorbed heavy metals from sea water and the local environment. A later hydrothermal event caused the galena to decompose, a variety of secondary minerals to form and conversion of the early Mn-rich material to manganese oxides. These formed an impervious layer around the lead-rich core, creating a closed system. As temperatures fell, a range of minerals including the lead oxychloride-dominated assemblage formed. Being closed, each system can have a unique chemistry dependent only on local starting conditions, and thus we see considerable variance in mineralogy from pod to pod.

The most abundant oxyhalide mineral in the assemblage is mendipite (Spencer, 1923). In most cases, any cavity containing mendipite is completely filled by a single mendipite crystal individual. Chloroxiphite, diaboleite, and paralaurionite occur in, and often entirely enclosed by, mendipite, and are usually also accompanied by malachite and occasionally by 


\section{3-024 \\ YEOMANITE}

mimetite and/or wulfenite.

In the mid 1970s a small number of specimens of mendipite were found that had a strikingly different appearance. Mendipite did not completely fill the cavity, there were small cavities in the mendipite itself, and the ends of otherwise typically columnar mendipite cleavages that adjoined these cavities had a distinctly fibrous appearance, resembling that of asbestos (Figure 1). This fibrous material has now been determined to consist of yeomanite.

Although known for many years, previous studies of what was then termed "fibrous mendipite" were inconclusive. This was partly due to a lack of material and partly due to its fibrous nature which resulted in poor results from X-ray studies. This was coupled with significant variability in chemical analyses. We have now found that the material contains variable amounts of other minerals including paralaurionite and mendipite. This probably explains the variability in chemistry and X-ray data obtained in earlier studies.

\section{APPEARANCE and PHYSICAL PROPERTIES}

Yeomanite appears to be formed of small, twisted, rope-like fibres growing from the end of columnar mendipite masses. Yeomanite fibres form loose mats and strands resembling asbestos (Figure 1). Individual fibres reach no more than $15 \mathrm{~mm}$ in length, and are generally $<8 \mathrm{~mm}$. Under magnification (Figure 2) the rope-like yeomanite fibres can be seen to be composed of twisted aggregates of minute hair-like crystals. We have also seen the fibrous material become detached from the columnar mendipite, forming loose masses of yeomanite. Colour: usually white, occasionally pale grey

Streak: white

Lustre: vitreous, transparent

Non-fluorescent

$\mathrm{H}\left(\mathrm{VHN}_{20}\right)=54.5 \mathrm{~kg} \mathrm{~mm}^{-2}(\mathrm{n}=2) ; \mathrm{H}($ Mohs $)=c a 1 \frac{1}{2}-2$

Tenacity: could not be determined due to the fibrous nature of the material

Cleavage: perfect, aligned with the long axis of the fibres. The precise crystallographic

orientation of the cleavage cannot be determined due to the nature of the material.

Parting: none observed

Fracture: could not be determined due to the fibrous nature of the material

Density could not be measured because of paucity of available material

Density (calc.) $=7.303 \mathrm{~g} \mathrm{~cm}^{-3}$ using the empirical formula

\section{OPTICAL PROPERTIES}

The material is non-metallic, but has a high RI typical of lead oxychlorides and has been studied using the methods common for metallic minerals to avoid using toxic RI liquids. In reflected light

Colour: light-grey to grey

Internal reflections: white

Nonpleochroic

Bireflectance: none observed

Anisotropism: $\Delta \mathrm{R}_{589}=3.58 \%$

Reflectance is shown graphically in Figure 3. Reflectance values ( $\mathrm{SiC}$ standard in air) are as follows: 


\section{3-024 \\ YEOMANITE}

\begin{tabular}{lll}
$\lambda, \mathrm{nm}$ & $\mathrm{R}_{\max } \%$ & $\mathrm{R}_{\min } \%$ \\
\hline 400 & 20.2 & 16.0 \\
420 & 19.5 & 15.4 \\
440 & 18.9 & 15.0 \\
460 & 18.6 & 14.7 \\
$\mathbf{4 7 0}$ & $\mathbf{1 8 . 4}$ & $\mathbf{1 4 . 5}$ \\
480 & 18.2 & 14.4 \\
500 & 17.8 & 14.1 \\
520 & 17.5 & 13.9 \\
540 & 17.3 & 13.7 \\
$\mathbf{5 4 6}$ & $\mathbf{1 7 . 2}$ & $\mathbf{1 3 . 7}$ \\
560 & 17.1 & 13.5 \\
580 & 16.9 & 13.3 \\
$\mathbf{5 8 9}$ & $\mathbf{1 6 . 8}$ & $\mathbf{1 3 . 3}$ \\
600 & 16.8 & 13.2 \\
620 & 16.7 & 13.1 \\
640 & 16.6 & 13.0 \\
$\mathbf{6 5 0}$ & $\mathbf{1 6 . 6}$ & $\mathbf{1 2 . 9}$ \\
660 & 16.6 & 12.8 \\
680 & 16.5 & 12.8 \\
700 & 16.4 & 12.8 \\
\hline
\end{tabular}

\section{CHEMICAL DATA}

Some 20 analyses were performed on three different crystals previously checked by single-crystal X-ray using a Camscan-4DV electron-scan microscope and an AN-10000 semiconductor spectrometer at $30 \mathrm{kV}$ and $0.7 \mathrm{nA}$ at the Radium Institute, St Petersburg. $\mathrm{Pb} L \alpha$ and $\mathrm{ClK \alpha}$ were used as analytical lines. The spectrum of the $\mathrm{PbM \alpha}$ line was subtracted because of its overlap with the $\mathrm{ClK \alpha}$ line. All calculations were made using AF4/FLS software. No elements other than those listed in Table 1 were detected. The hydroxyl component was calculated on the basis of structural considerations as insufficient sample exists for determination via $\mathrm{CHN}$ and/or any other analysis technique.

Table 1. Analytical data for yeomanite.

\begin{tabular}{|c|c|c|c|c|}
\hline Constituent & wt\% & Range & SD & Standards \\
\hline $\mathrm{PbO}$ & 92.31 & $91.97-92.50$ & 0.39 & Pyromorphite \\
\hline $\mathrm{Cl}$ & 7.40 & $7.35-7.48$ & 0.14 & Pyromorphite \\
\hline $\mathrm{H}_{2} \mathrm{O}$ & 1.88 & & & \\
\hline $\mathrm{O}=\mathrm{Cl}$ & -1.67 & & & \\
\hline Total & 99.92 & & & \\
\hline
\end{tabular}

The empirical formula (based on 3 anions $p f u$ ) is $\mathrm{Pb}_{1.99} \mathrm{O}_{0.98}(\mathrm{OH})_{1.01} \mathrm{Cl}_{1.01}$. The simplified formula is $\mathrm{Pb}_{2} \mathrm{O}(\mathrm{OH}) \mathrm{Cl}$, which requires $\mathrm{PbO} 92.45, \mathrm{Cl} 7.34, \mathrm{H}_{2} \mathrm{O}$ 1.87, $\mathrm{O}=\mathrm{Cl}-1.66$, total $100.00 \mathrm{wt} \%$. 


\section{3-024 \\ YEOMANITE}

\section{CRYSTALLOGRAPHY}

A well-formed, thin, needle-like crystal was studied using a Bruker Smart Apex II diffractometer at the Department of Crystallography, St Petersburg State University, and gave the following data.

\begin{tabular}{|c|c|}
\hline $\begin{array}{l}\text { Orthorhombic } \\
a=6.585(10) \AA \\
V=438(1) \AA^{3}\end{array}$ & $\begin{array}{l}\text { Space group: Pnma } \\
b=3.855(6) \AA \\
Z=4\end{array}$ \\
\hline
\end{tabular}

Preliminary X-ray powder measurements revealed that yeomanite forms intergrowths with paralaurionite. Thus it was decided to hand pick 20 homogenous fibrous crystals of yeomanite under the microscope. These were subsequently crushed and mounted in an epoxy ball on a glass fibre. X-ray powder diffraction data were obtained using a Stoe Image Plate System at the Department of Crystallography, St Petersburg State University. Data (in $\AA$ for MoKa) are listed in Table 2. Unit cell parameters refined from the powder data are as follows. Orthorhombic Space group: Pnma $a=6.58(1) \AA \quad b=3.86(1) \AA \quad c=17.23(3) \AA$ $V=437(1) \AA^{3} \quad Z=4$

Crystal structure: $R_{1}=0.106$ for 329 unique observed reflections.

Yeomanite forms asbestos-like mats of intergrown crystals, which diffract rather poorly under the X-ray beam. Consequently, eleven different crystals were independently checked to ensure that results were consistent. The nature of the material meant that no individual yeomanite crystal that could provide a "perfect" single-crystal study was found. The results reported here were obtained from the best analysis.

A very thin, needle-like crystal $(0.18 \times 0.001 \times 0.001 \mathrm{~mm})$ was mounted on a Bruker APEX II DUO X-ray diffractometer with a micro-focus X-ray tube operating with MoKa radiation at $50 \mathrm{kV}$ and $40 \mathrm{~mA}$. The data were integrated and corrected for absorption using a multi-scan model and the Bruker programs APEX and SADABS. More than a hemisphere of data was collected for each crystal with frame widths of $0.3^{\circ}$ in $\omega$, and with 280 s counting per frame. The structure was solved by direct methods and refined to $R_{1}=0.106$ for 329 unique observed reflections.

The structure was solved first in space group $P \overline{1}$. The obtained structure model was transformed to the orthorhombic space group Pnma using the ADDSYM algorithm incorporated in the PLATON program package (le Page, 1987; Spek, 2003). Generally, the structure of yeomanite belongs to a family of $\mathrm{Pb}$ oxyhalide minerals based on oxo-centred $\mathrm{OPb}_{4}$ units. The coordination spheres of both $\mathrm{Pb}(1)$ and $\mathrm{Pb}(2)$ atoms (Figure 4 and Table 3 ) clearly indicate the stereochemical activity of the lone electron pairs on $\mathrm{Pb}^{2+}$ cations. Because of the large size and variability of coordination polyhedra around $\mathrm{Pb}^{2+}$ cations and the high strength of $\mathrm{Me}-\mathrm{O}, \mathrm{Me}-\mathrm{OH}$ bonds in comparison to $\mathrm{Me}-\mathrm{Cl}$ bonds $(\mathrm{Me}=$ metal), it is therefore convenient to describe the structure of yeomanite (Figure 5) in terms of oxo-centred $\mathrm{OPb}_{4}$ tetrahedra and hydroxo-centered $\mathrm{OHPb}_{3}$ triangles.

The structure contains two independent $\mathrm{O}$ atoms. $\mathrm{O} 2$ belongs to the hydroxyl group and its valence requirements are strongly influenced by the formation of the $\mathrm{O}-\mathrm{H}$ bonds (Table 4). $\mathrm{O} 1$ is tetrahedrally coordinated by four $\mathrm{Pb}^{2+}$ cations forming relatively short and strong $\mathrm{O}-\mathrm{Pb}$ bonds. From the viewpoint of bond valence theory, these bonds are the strongest 


\section{3-024 \\ YEOMANITE}

in the structure and thus it makes sense to consider the $\mathrm{O}^{2-}$ anions as coordination centres for the oxo-centered $\mathrm{OPb}_{4}$ tetrahedra. The mean $\mathrm{O}-\mathrm{Pb}$ length in the $\mathrm{O}_{\mathrm{Pb}}$ tetrahedron is $2.31 \AA$ which is typical for such units (Krivovichev et al., 1998). The $\mathrm{OPb}_{4}$ tetrahedra link together via common edges and corners to form $\left[\mathrm{OPb}_{2}\right]^{2+}$ chains (Figure 6a). Oxygen atoms belonging to hydroxyl groups are additionally attached to these chains thus forming novel one dimensional $\left[\mathrm{O}(\mathrm{OH}) \mathrm{Pb}_{2}\right]^{+}$units. These are elongated along the $b$ axis and occur in both parallel and mutually perpendicular orientations. The positively charged $\left[\mathrm{O}(\mathrm{OH}) \mathrm{Pb}_{2}\right]^{+}$chains are linked one with each other via rather weak $\mathrm{Pb}-\mathrm{Cl}$ bonds thus providing the 3D integrity of the structure of yeomanite. Atom coordinates, displacement parameters and selected bond lengths are given in Tables 3 and 4, respectively.

The structure of yeomanite is a new example of a lead oxyhalide based upon novel $\left[\mathrm{O}(\mathrm{OH}) \mathrm{Pb}_{2}\right]^{+}$chains. Though similar $\left[\mathrm{OPb}_{2}\right]^{2+}$ chains have previously been observed in the structure of sidpietersite, $\left[\mathrm{Pb}_{4} \mathrm{O}_{2}\right]\left(\mathrm{S}_{2} \mathrm{O}_{3}\right)(\mathrm{OH})_{2}$ (Figure 6b; Cooper and Hawthorne, 1999), However, the hydroxyl groups in that mineral are arranged in a very different way and do not result in the subsequent formation of $\mathrm{OHPb}_{3}$ triangles. Similarly, the structures of penfieldite, $\mathrm{Pb}_{2}(\mathrm{OH}) \mathrm{Cl}_{3}$ (Merlino et al., 1995) and laurionite, $\mathrm{Pb}(\mathrm{OH}) \mathrm{Cl}$ (Venetopoulos and Rentzeperis, 1975) are based on $[\mathrm{OHPb}]^{+}$and $\left[\mathrm{OHPb}_{2}\right]^{3+}$ chains formed by corner sharing and edge sharing $\mathrm{OHPb}_{3}$ triangles, respectively (Figure $6 \mathrm{c}, \mathrm{d}$ ). This observation indicates the structural relationship of yeomanite to both of these minerals, and collectively allows one to consider the $\left[\mathrm{O}(\mathrm{OH}) \mathrm{Pb}_{2}\right]^{+}$band as being built up from an $\left[\mathrm{OPb}_{2}\right]^{2+}$ oxo-centered chain with attached hydroxo-centered $\left[\mathrm{OHPb}_{2}\right]^{3+}$ penfieldite chains on both sides. The crystal structure of plumbonacrite, $\mathrm{Pb}_{5} \mathrm{O}(\mathrm{OH})_{2}\left(\mathrm{CO}_{3}\right)_{3}$ (Williams et al, 2012) also contains $\left[(\mathrm{OH}) \mathrm{Pb}_{3}\right]$ triangles, but these form $\left[\mathrm{O}(\mathrm{OH})_{3} \mathrm{~Pb}_{7}\right]$ clusters.

It is also of interest that yeomanite is not structurally related to damaraite, $\mathrm{Pb}_{3} \mathrm{O}_{2}(\mathrm{OH}) \mathrm{Cl}$ (Keller et al., 2001). The crystal structure of damaraite is based on $\left[\mathrm{O}_{2} \mathrm{~Pb}_{3}\right]^{2+}$ oxo-centered double chains (Figure 6e) which are linked through $\mathrm{OH}$ groups to form $\left[\mathrm{Pb}_{3} \mathrm{O}_{2}\right](\mathrm{OH})$ sheets. $\mathrm{OH}$ groups form two short $(\mathrm{OH})-\mathrm{Pb}$ bonds that result in $(\mathrm{OH}) \mathrm{Pb}_{2}$ dimers. The $\left[\mathrm{O}_{2} \mathrm{~Pb}_{3}\right]^{2+}$ chains in damaraite are the main building units in the growing number of "Mendipite Group" minerals mendipite, damaraite, chloroxiphite, and rickturnerite. Yeomanite is also not structurally related to blixite, $\mathrm{Pb}_{8} \mathrm{O}_{5}(\mathrm{OH})_{2} \mathrm{Cl}_{4}$ (Krivovichev and Burns, 2006) which is based on $\left[\mathrm{O}_{5} \mathrm{~Pb}_{8}\right]$ layers related to the structure of litharge (Siidra et al., 2013).

\section{Morphology}

Habit: fibrous

Forms: impossible to determine due to the fibrous nature of the material

Twinning: none observed

The $a: b: c$ ratio calculated from the unit-cell parameters is $1.708: 1: 4.477$

\section{NAME}

Yeomanite is named in joint recognition of Mrs Angela Yeoman (1931 - ) and her company, Foster Yeoman Ltd, who operated Merehead Quarry for aggregate until 2006. Mrs Yeoman has accepted the proposal on behalf of both Foster Yeoman Ltd and herself.

Mrs Yeoman took a personal interest in collecting, conservation, and research work at Merehead and her company actively supported these activities for nearly 50 years. In addition to allowing access to the quarry, practical assistance was often provided in the form of heavy earth moving plant to excavate newly exposed manganese pods or veins, and interesting material found when researchers were not present was frequently removed by company staff 


\section{3-024 \\ YEOMANITE}

and stockpiled for later investigation. As a direct result of this cooperation, it has been possible to study the highly unusual manganese pod mineralisation in situ, and in considerable detail for some decades. This is now reflected in the number of mineral species identified from the quarry, approximately 70, of which about 15 are unusual $\mathrm{Pb}$ oxyhalide or oxycarbonate minerals (Turner and Rumsey, 2010). Merehead is the type locality for six of these (mereheadite, parkinsonite, rickturnerite, rumseyite, symesite, yeomanite) and is also the neotype locality for plumbonacrite.

The generosity shown by Mrs Yeoman and Foster Yeoman Ltd in allowing access to mineral collectors' means that many fine examples of these rare minerals are now housed in public and private collections throughout the world. Finally, the opportunity to closely study a statistically significant number of manganese pods in situ allowed observations to be made that eventually permitted the complex processes behind manganese pod formation to be determined (Turner, 2006).

\section{TYPE MATERIAL}

The holotype specimen is stored in the collections of the Natural History Museum, Cromwell Road, London SW7 5BD, UK, under catalogue number BM 2013,5.

\section{RELATION TO OTHER SPECIES}

Yeomanite represents a new structure type, which is most closely related to those of sidpietersite, penfieldite and laurionite.

\section{COMPATIBILITY}

Compatibility could not be calculated.

\section{REFERENCES}

Brese, N.E. and O'Keeffe, M. (1991) Bond-valence parameters for solids. Acta Crystallographica, B47, 192-197.

Cooper, M.A. and Hawthorne, F.C. (1999) The structure topology of sidpietersite, $\mathrm{Pb}_{4}^{2+} \mathrm{S}^{6+} \mathrm{O}_{3} \mathrm{~S}^{2-} \mathrm{O}_{2}(\mathrm{OH})_{2}$, a novel thiosulfate structure. Canadian Mineralogist, 37, 12751282.

Keller, P., Lissner, F. and Schleid, T. (2001) Damaraite, $\mathrm{Pb}_{3} \mathrm{O}_{2}(\mathrm{OH}) \mathrm{Cl}$ : crystal structure and new chemical formula. Neues Jahrbuch für Mineralogie, Monatshefte, 326-336.

Krivovichev, S.V. and Brown, I.D. (2001) Are the compressive effects of encapsulation an artifact of the bond valence parameters? Zeitschrift für Kristallographie, 216, 245-247.

Krivovichev, S.V. and Burns, P.C. (2006) The crystal structure of $\mathrm{Pb}_{8} \mathrm{O}_{5}(\mathrm{OH})_{2} \mathrm{Cl}_{4}$, a synthetic analogue of blixite? Canadian Mineralogist, 44, 515-522.

Krivovichev, S.V., Filatov, S.K. and Semenova, T.F. (1998) Types of cationic complexes on the base of oxocentered tetrahedra $\left[\mathrm{OM}_{4}\right]$ in crystal structures of inorganic compounds. Russian Chemical Reviews, 67, 137-155.

le Page, Y. (1987) Computer derivation of the symmetry elements implied in a structure description. Journal of Applied Crystallography, 20, 264-269.

Merlino, S., Pasero, M., Perchiazzi, N. and Gianfagna, A. (1995) X-ray and electron diffraction study of penfieldite: average structure and multiple cells. Mineralogical Magazine, 59, 341-347

Siidra, O. I., Krivovichev, S.V., Turner, R.W., Rumsey, M.S. and Spratt, J. (2013) Crystal chemistry of layered $\mathrm{Pb}$ oxychloride minerals with $\mathrm{PbO}$-related structures. Crystal 


\section{YEOMANITE}

structure of hereroite, $\left[\mathrm{Pb}_{32} \mathrm{O}_{20}(\mathrm{O}, \square)\right]\left(\mathrm{AsO}_{4}\right)_{2}\left((\mathrm{Si}, \mathrm{As}, \mathrm{V}, \mathrm{Mo}) \mathrm{O}_{4}\right)_{2} \mathrm{Cl}_{10}$. American Mineralogist, in press.

Spek, A.L., (2003) Single-crystal structure validation with the program PLATON. Journal of Applied Crystallography, 36, 7-13.

Spencer. L.J. and Mountain, E.D. (1923) New lead-copper minerals from the Mendip Hills, Somerset. Mineralogical Magazine, 20, 67-92.

Turner, R.W. (2006) A mechanism for the formation of the mineralised manganese deposits at Merehead Quarry, Cranmore, Somerset, England. Mineralogical Magazine, 70, 629653.

Turner, R.W. and Rumsey, M.S. (2010) Mineral Relationships in the Mendip Hills. Journal of the Russell Society, 13, 3-47.

Venetopoulos, C.C. and Rentzeperis, P.J. (1975) The crystal structure of laurionite, $\mathrm{Pb}(\mathrm{OH}) \mathrm{Cl}$. Zeitschrift für Kristallographie, 141, 246-259.

Williams, P.A., Hatert, F., Pasero, M., and Mills, S.J. (2012). New Minerals and

Nomenclature Modifications Approved in 2012. Mineralogical Magazine, October 2012,

Vol. 76(5), 1281-1288

\section{AUTHORS' REMARKS}

Nil

\section{CHAIRMAN'S REMARKS}

Nil 
Table 2. Powder X-ray data for yeomanite.

\begin{tabular}{|c|c|c|c|c|c|}
\hline$I_{\text {rel }}$ & $d_{\text {obs }}$ & $d_{\text {calc }}$ & $h$ & $k$ & $l$ \\
\hline 9 & 8.628 & 8.630 & 0 & 0 & 2 \\
\hline 7 & 6.114 & 6.152 & 1 & 0 & 1 \\
\hline 9 & 5.246 & 5.235 & 1 & 0 & 2 \\
\hline 2 & 4.340 & 4.333 & 1 & 0 & 3 \\
\hline 32 & 3.770 & 3.762 & $\mathbf{0}$ & 1 & 1 \\
\hline 11 & 3.605 & 3.609 & 1 & 0 & 4 \\
\hline 61 & 3.293 & 3.293 & 2 & $\mathbf{0}$ & $\mathbf{0}$ \\
\hline 12 & 3.267 & 3.267 & 1 & 1 & 1 \\
\hline 11 & 3.241 & 3.234 & 2 & 0 & 1 \\
\hline 5 & 3.098 & 3.104 & 1 & 1 & 2 \\
\hline 4 & 3.077 & 3.076 & 2 & 0 & 2 \\
\hline 17 & 3.054 & $\mathbf{3 . 0 5 7}$ & 1 & $\mathbf{0}$ & 5 \\
\hline 100 & 2.880 & 2.880 & 1 & 1 & 3 \\
\hline 78 & 2.802 & 2.877 & $\mathbf{0}$ & 0 & 6 \\
\hline 4 & 2.617 & 2.618 & 2 & 0 & 4 \\
\hline 6 & 2.493 & 2.504 & 2 & 1 & 0 \\
\hline 11 & 2.471 & 2.478 & 2 & 1 & 1 \\
\hline 10 & 2.414 & 2.405 & 2 & 1 & 2 \\
\hline 8 & 2.180 & 2.178 & 3 & 0 & 1 \\
\hline 22 & 2.166 & 2.166 & 2 & $\mathbf{0}$ & 6 \\
\hline 15 & 2.165 & 2.166 & 2 & 1 & 4 \\
\hline 7 & 2.080 & 2.077 & 0 & 1 & 7 \\
\hline 18 & 2.050 & 2.051 & 3 & 0 & 3 \\
\hline 14 & 1.928 & 1.928 & 0 & 2 & 0 \\
\hline 6 & 1.900 & 1.896 & 3 & 1 & 1 \\
\hline 13 & 1.811 & 1.811 & 3 & 1 & 3 \\
\hline 9 & 1.663 & 1.663 & 2 & 2 & 0 \\
\hline 19 & 1.662 & 1.662 & 1 & 1 & 9 \\
\hline 11 & 1.602 & 1.601 & 0 & 2 & 6 \\
\hline 7 & 1.491 & 1.491 & 4 & 1 & 2 \\
\hline 4 & 1.486 & 1.486 & 4 & 0 & 5 \\
\hline 5 & 1.440 & 1.440 & 2 & 2 & 6 \\
\hline 2 & 1.438 & 1.438 & 0 & 0 & 12 \\
\hline 6 & 1.445 & 1.437 & 0 & 2 & 8 \\
\hline
\end{tabular}




\section{3-024}

\section{YEOMANITE}

Table 3. Atom coordinates and displacement parameters $\left(\AA^{2}\right)$ for yeomanite.

\begin{tabular}{|c|c|c|c|c|c|c|c|c|c|c|c|}
\hline Atom & B.V.S.* & $x / a$ & $y / b$ & $z / c$ & $U_{\mathrm{eq}}$ & $U_{11}$ & $U_{22}$ & $U_{33}$ & $U_{23}$ & $U_{13}$ & $U_{12}$ \\
\hline $\mathrm{Pb}(1)$ & 1.84 & $0.2683(4)$ & $3 / 4$ & $0.01645(19)$ & $0.0171(13)$ & $0.0062(17)$ & $0.011(3)$ & $0.0346(19)$ & 0.000 & $0.000(1)$ & 0.000 \\
\hline $\mathrm{Pb}(2)$ & 1.90 & $0.6862(5)$ & $3 / 4$ & $0.17093(17)$ & $0.0181(13)$ & $0.0091(19)$ & $0.012(3)$ & $0.0334(18)$ & 0.000 & $-0.002(1)$ & 0.000 \\
\hline $\mathrm{Cl}(1)$ & 0.60 & $0.330(4)$ & $1 / 4$ & $0.1683(12)$ & $0.028(6)$ & $0.035(14)$ & $0.015(18)$ & $0.035(11)$ & 0.000 & $0.002(9)$ & 0.000 \\
\hline $\mathrm{O}(1) * *$ & 2.01 & 0.6106 & $3 / 4$ & 0.0506 & 0.050 & 0.050 & 0.050 & 0.050 & 0.000 & 0.000 & 0.000 \\
\hline $\mathrm{OH}^{* *}$ & 1.14 & 0.1415 & $3 / 4$ & -0.1248 & 0.050 & 0.050 & 0.050 & 0.050 & 0.000 & 0.000 & 0.000 \\
\hline
\end{tabular}

bonds and from Brese and O'Keeffe (1991) for other bonds. **Fixed during refinement.

Table 4. Selected bond lengths $(\AA)$ in the structure of yeomanite.

\begin{tabular}{|l|l|}
\hline $\mathrm{Pb}(1)-\mathrm{O}(1)$ & $2.330(4)$ \\
\hline $\mathrm{Pb}(1)-\mathrm{O}(1)$ & $2.385(3) \times 2$ \\
\hline $\mathrm{Pb}(1)-\mathrm{OH}$ & $2.576(5)$ \\
\hline $\mathrm{Pb}(1)-\mathrm{Cl}(1)$ & $3.278(18) \times 2$ \\
\hline & \\
\hline $\mathrm{Pb}(2)-\mathrm{O}(1)$ & $2.136(5)$ \\
\hline $\mathrm{Pb}(2)-\mathrm{OH}$ & $2.375(3) \times 2$ \\
\hline $\mathrm{Pb}(2)-\mathrm{Cl}(1)$ & $3.04(2) \times 2$ \\
\hline $\mathrm{Pb}(2)-\mathrm{Cl}(1)$ & $3.51(2) \times 2$ \\
\hline
\end{tabular}




\section{3-024 \\ YEOMANITE}

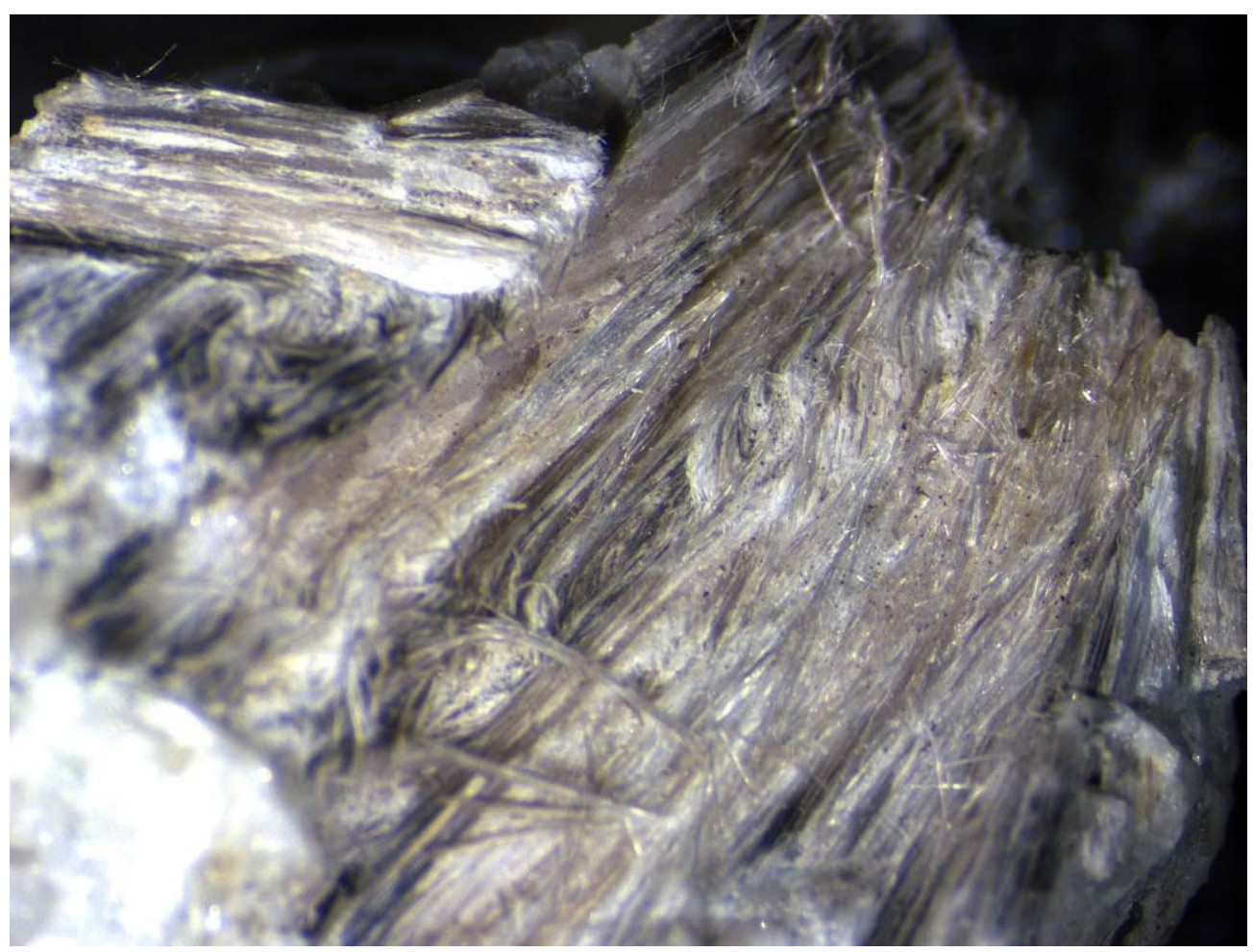

Figure 1 . The distinctive fibrous appearance of yeomanite. FoV approximately $10 \mathrm{~mm}$.

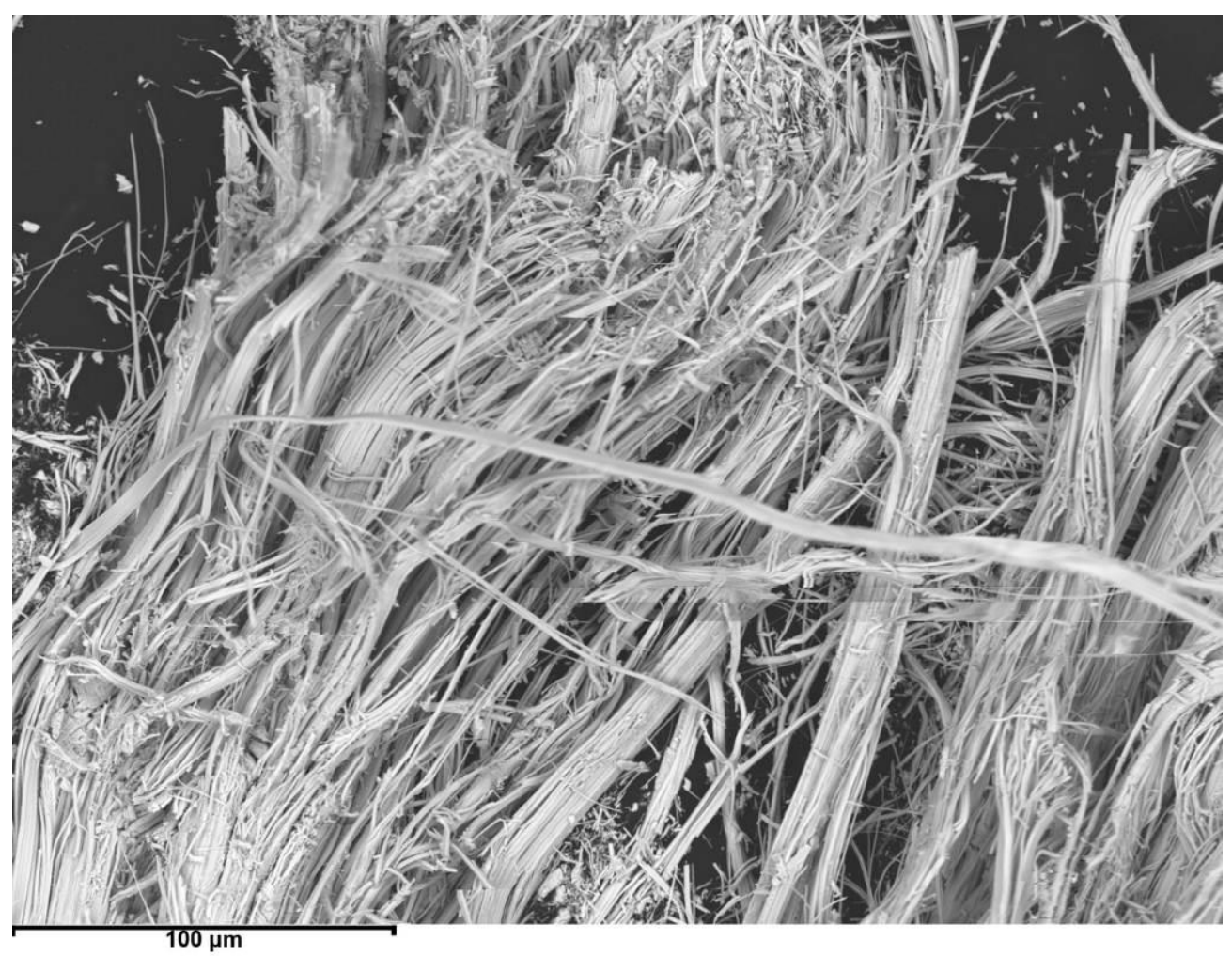

Figure 2. SEM image of yeomanite fibres. 


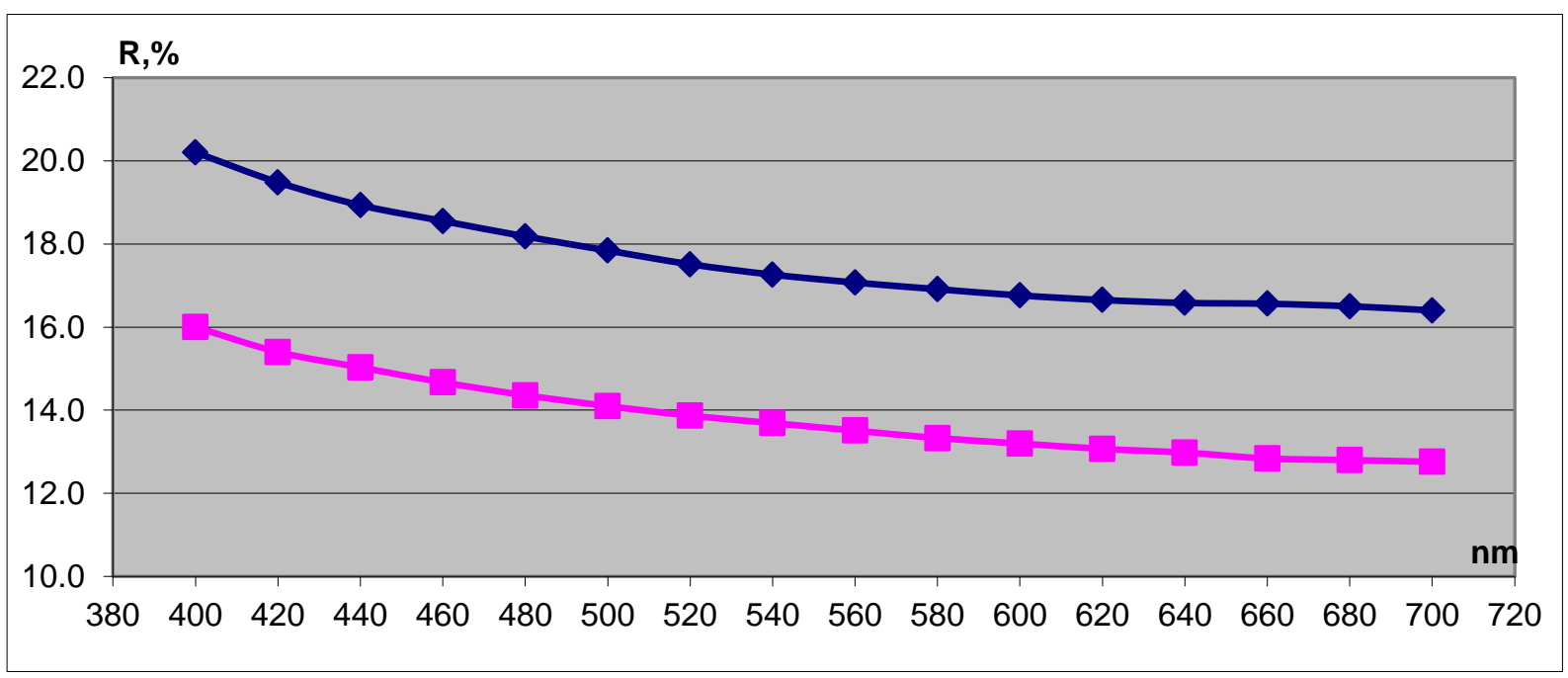

Figure 3. Graphical reflectance values for yeomanite.

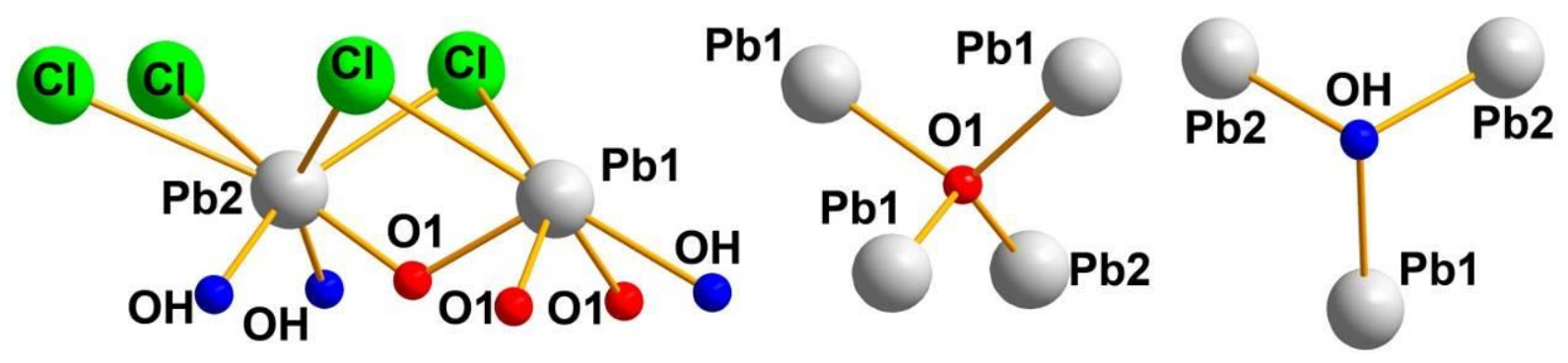

Figure 4. Atom coordination in the crystal structure of yeomanite, $\mathrm{Pb}_{2} \mathrm{O}(\mathrm{OH}) \mathrm{Cl}$.

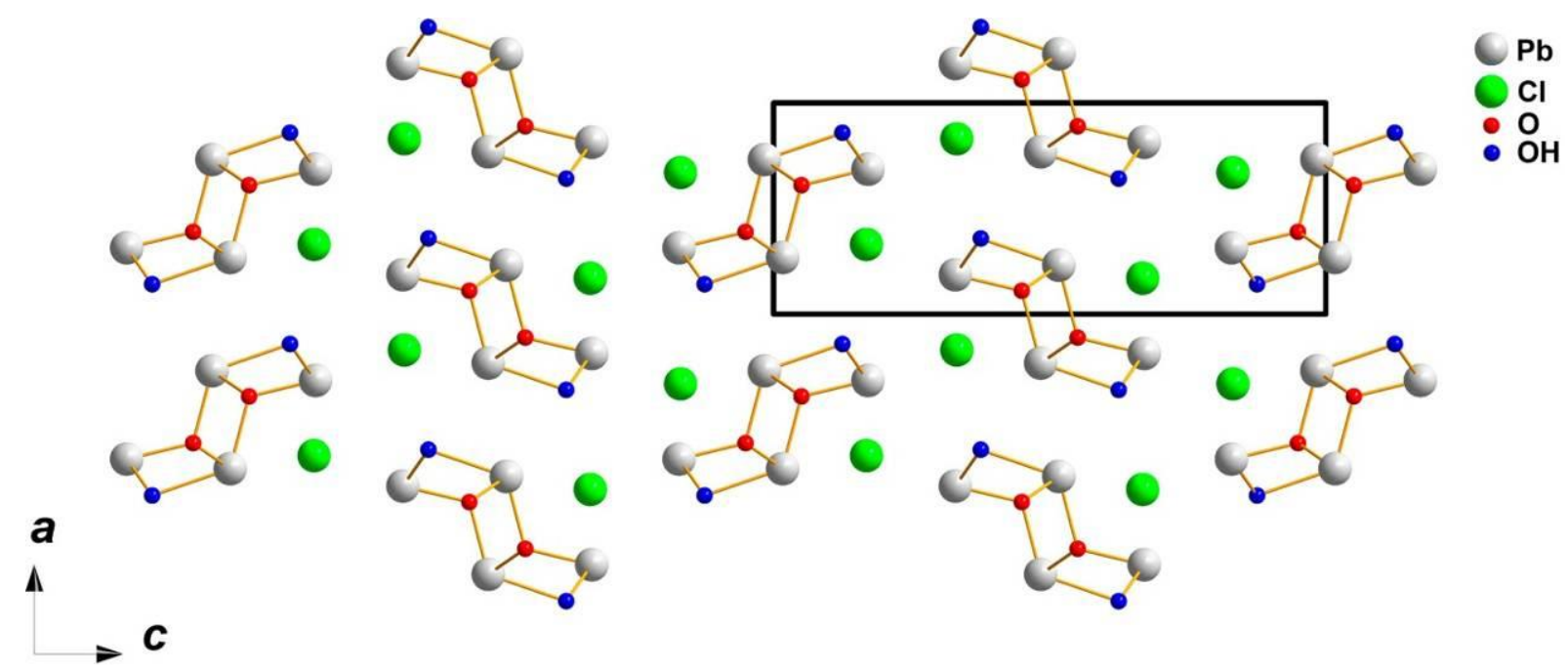

Figure 5. General projection of the crystal structure of yeomanite along the $b$ axis. 
(a)

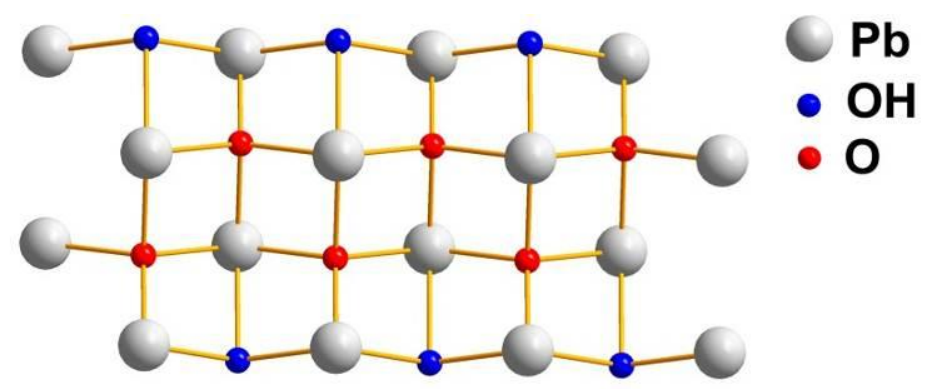

(b)

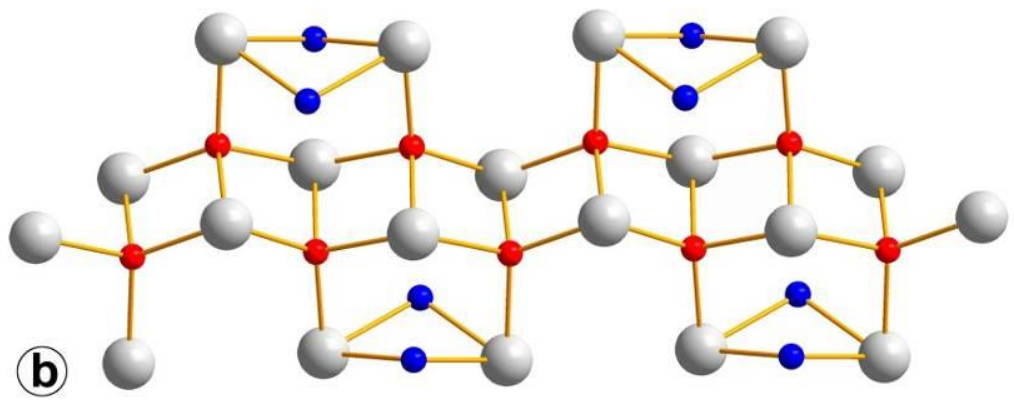

C)

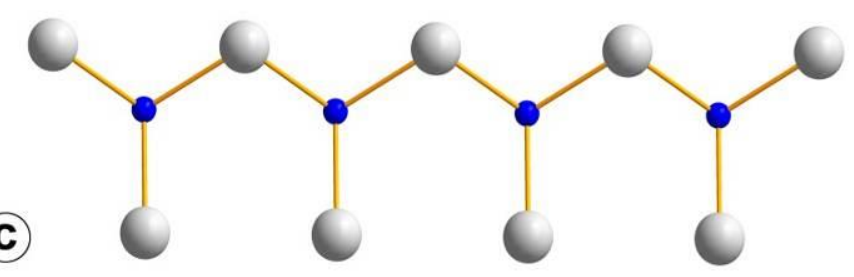

(d)

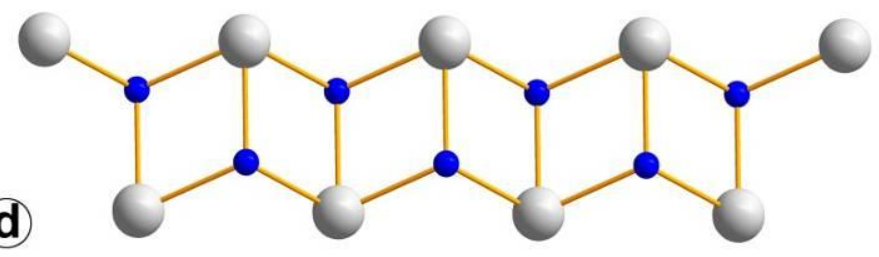

(e)

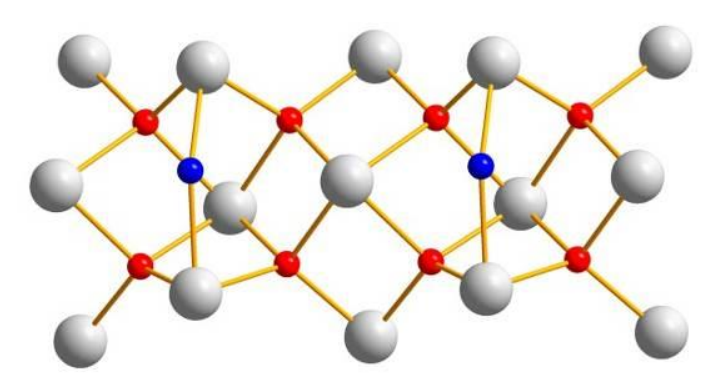

Figure 6. 1D dimensional units in the structures of $\mathrm{Pb}$ oxy/hydroxychloride minerals; (a): yeomanite; (b): sidpietersite; (c): penfieldite; (d): laurionite; (e): damaraite. 